\title{
POLA PENYERAPAN NUTRISI ENDOGEN DAN PERKEMBANGAN MORFOLOGIS PADA STADIA AWAL LARVA IKAN NAPOLEON (Cheilinus undulatus)
}

\author{
Philip Teguh Imanto, Regina Melianawati, dan Bejo Slamet
}

\begin{abstract}
ABSTRAK
Penelitian bertujuan untuk mengetahui aktivitas penyerapan nutrisi endogenous dan waktu terjadinya kelengkapan morfologis larva ikan napoleon stadia awal. Hasil yang diperoleh diharapkan dapat menjadi pengetahuan dasar untuk menunjang kegiatan budi dayanya. Larva yang digunakan untuk penelitian ini berasal dari telur hasil pemijahan alami induk ikan napoleon yang dipelihara dalam tangki beton. Hasil pengamatan menunjukkan bahwa larva yang baru menetas berukuran panjang total $1,97 \pm 0,06 \mathrm{~mm}$; volume kuning telur $421,8 \times 10^{-4} \mathrm{~mm}^{3}$; dan volume butir minyak $14,89 \times 10^{-4} \mathrm{~mm}^{3}$. Pertumbuhan larva terbagi dalam 3 tahap, yang pertama berlangsung cepat seiring dengan kecepatan penyerapan kuning telur hingga 40 jam pertama. Kemudian tahap perkembangan yang menurun selama kurang lebih 35 jam dan meningkat lagi mulai 75 jam setelah menetas. Penyerapan butir minyak paling cepat berlangsung pada 36-68 jam setelah menetas. Kuning telur larva habis terserap pada \pm 70 jam setelah menetas. Awal pigmentasi mata dan bukaan mulut larva masing-masing terjadi pada 36 jam dan 53 jam setelah menetas. Penyerapan nutrisi endogenous yang berasal dari kuning telur lebih banyak digunakan untuk pertumbuhan/kelengkapan morfologis, sedang nutrisi/energi yang berasal dari butir minyak digunakan untuk aktivitas organ dalam serta pergerakan tubuh. Sediaan pakan awal bagi larva disarankan mulai diberikan 60 jam setelah menetas dengan ukuran pakan tidak melebihi 120 mikron.
\end{abstract}

\begin{abstract}
The endogenous absorption and morphological development on initial stage of napoleon fish (Cheilinus undulatus) larvae. By: Philip Teguh Imanto, Regina Melianawati, and Bejo Slamet

The observation was conducted to study the endogenous absorption activity and morphological development on initial state of napoleon fish larvae. The result can be used for basic data on the fish seed production. Larvae used in this observation came from the natural spawning of napoleon broodstock, reared in the concrete tank. The result showed that newly hatched larvae has $1.97 \pm 0.06 \mathrm{~mm}$ total length, $421.8 \times 10^{-4} \mathrm{~mm}^{3}$ yolk volume, and $14.89 \times 10^{-4} \mathrm{~mm}^{3}$ oil globule. Lanal growth were divided into 3 stage. The first stage was fast growth and within the same time fast yolk absorption until 40 hours after hatching (HAH). In the second stage, negative growth appeared for around 35 hours after, while in the third stage, total length increased after $75 \mathrm{HAH}$. Fast oil globule absorption occured at 36-68 HAH. Complete yolk absorption was in $70 \mathrm{HAH}$. Starting of eye pigmentation and mouth opening were noticed in 36 and $53 \mathrm{HAH}$ respectivelly. The nutrition absorption from yolk were mostly used for morphological and organ development. Energy from oil globule was used for activity of internal organ and body movement. Initial feeding should be prepared at least in $60 \mathrm{HAH}$ with life food not more than 120 micron in size.
\end{abstract}

KEYWORDS: larvae, endogenous energy, napoleon fish

\section{PENDAHULUAN}

Ikan napoleon (Cheilinus undulatus) merupakan salah satu jenis ikan laut ekonomis penting di pasar Asia terutama Hongkong dan Singapura, karena harganya yang tergolong tinggi (Yunus et al., 1999). Dalam keadaan hidup harga ikan penghuni terumbu karang ini merupakan yang termahal dibanding ikan konsumsi lainnya (Slamet et al., 2000).
Tingginya nilai ekonomis dan permintaan pasar mengakibatkan keberadaan ikan napoleon semakin terancam akibat kegiatan perburuan yang terus meningkat dan penangkapan yang menggunakan bahan kimia seperti potasium/kalium sianida yang berakibat pada kerusakan habitatnya (Anonim, 1995). Oleh karena itu, pengembangan usaha budi daya merupakan upaya yang perlu dilakukan untuk mengimbangi laju penurunan populasi dan sekaligus

Peneliti pada Balai Besar Riset Perikanan Budidaya Laut, Gondol 
menjaga kelestariannya di alam (Yunus et al., 1999). Usaha budi daya ikan ini telah dilakukan di Kepulauan Seribu dan Riau namun masih dalam skala kecil dan hanya merupakan usaha penampungan atau pembesaran hasil tangkapan di alam sampai ukuran konsumsi (Slamet \& Imanto, 1997).

Balai Besar Riset Perikanan Budidaya Laut, Gondol telah berhasil melakukan aklimatisasi indukinduk ikan napoleon yang berasal dari alam, memelihara, dan menyiapkan induk siap pijah di dalam tangki beton, dengan pemberian pakan segar berupa ikan dan cumi-cumi serta pelet basah (Slamet et al., 1999), sedang untuk pemeliharaan larvanya belum dapat dilaksanakan secara maksimal karena masih tingginya kematian pada stadia awal kehidupan larva (Ismi et al., 2000). Untuk keberhasilan kegiatan pembenihan/pemeliharaan larva ikan napoleon ini masih sangat diperlukan informasi-informasi dasar. Pengenalan pada perkembangan awal larva ikan napoleon yang meliputi perkembangan morfologis, ketersediaan sumber energi dalam tubuh (endogenous energy) hingga perkembangan organ untuk mendapatkan sumber energi dari luar (exogenous energy) sangat diperlukan untuk menentukan upayaupaya pemeliharaannya.

Penelitian ini dilakukan untuk mengetahui aktivitas dan laju penyerapan nutrisi endogenous energy dan waktu terjadinya kelengkapan morfologis pada stadia awal kehidupan larva. Pengetahuan ini merupakan salah satu data dasar (base data) yang penting untuk diketahui sebagai dasar bagi kegiatan pembenihannya yang merupakan rantai awal kegiatan budi daya terhadap ikan ini.

\section{BAHAN DAN METODE}

Penelitian dílakukan di Laboratorium Balai Besar Riset Perikanan Budidaya Laut, Gondol-Bali pada bulan Agustus dan September 2000. Larva yang digunakan untuk pengamatan berasal dari telur hasil pemijahan induk ikan napoleon secara alami yang dipelihara pada tangki beton bervolume $50 \mathrm{~m}^{3}$. Pemijahan terjadi antara pukul $15 .^{\circ 0}-17 . .^{\circ} \mathrm{WITA}$. Telur hasil pemijahan selanjutnya akan terkumpul dalam kolektor berukuran $50 \times 50 \times 50 \mathrm{~cm}^{3}$ yang berada di sisi luar tangki induk. Sesaat setelah pemijahan berlangsung, telur di dalam kolektor diambil secara hati-hati dengan menggunakan serok telur untuk selanjutnya dilakukan seleksi. Telur yang digunakan untuk penelitian adalah telur yang dibuahi.

Telur kemudian diinkubasikan dalam wadah plastik berbentuk empat persegi panjang dengan volume \pm 45 liter. Inkubasi dilakukan di dalam ruangan (indoor) dengan kondisi air laut berkadar garam 33 ppt dan suhu media berkisar $29-30^{\circ} \mathrm{C}$, ke dalam tangki inkubasi ditambahkan pula aerasi lemah. Setelah telur menetas dilakukan penyiponan pada bagian dasar tangki untuk membuang cangkang dan telur yang tidak menetas. Hal ini dilakukan untuk menjaga kualitas air dalam media pemeliharaan tersebut.

Pengamatan dimulai tepat pada saat telur menetas dengan mengambil sejumlah sampel larva dan kemudian mengamatinya dengan stereoskopis mikroskop Olympus yang telah dilengkapi dengan micrometer. Interval waktu pengamatan adalah setiap tiga jam sekali, namun apabila kelengkapan morfologis larva berupa pigmentasi mata dan bukaan mulut telah terbentuk, maka pengamatan selanjutnya dilakukan dengan interval waktu 24 jam. Jumlah sampel larva untuk setiap kali pengamatan adalah 5 ekor. Selama masa pemeliharaan ini larva berada dalam kondisi tanpa pakan (unfed larvae).

Adapun peubah yang diamati meliputi panjang total larva (total length), volume kuning telur (yolk), dan volume butir minyak (oil globule), waktu terjadinya pigmentasi mata dan lebar mulut pada saat mulut sudah membuka. Volume kuning telur dan volume butir minyak dihitung berdasarkan rumus yang diuraikan oleh Blaxter \& Hempel (1963) dalam Kohno et al. (1986). Semua hasil perhitungan peubah merupakan nilai rata-rata dari semua sampel yang diamati.

\section{HASIL DAN BAHASAN}

Hasil pengamatan pada stadia awal larva napoleon (Gambar 1) menunjukkan bahwa panjang total larva pada saat menetas tercatat 1,97 $\pm 0,06 \mathrm{~mm}$; volume kuning telur adalah $421,8 \times 10^{-4} \mathrm{~mm}^{3}$; dan volume butir minyak sebesar $14,89 \times 10^{-4} \mathrm{~mm}^{3}$.

Panjang total larva napoleon yang baru menetas relatif lebih kecil bila dibandingkan dengan jenis larva kakap merah, namun sedikit lebih besar dibandingkan dengan jenis larva kerapu. Larva kakap merah, Lutjanus sebae yang baru menetas, hasil pemijahan di keramba jaring apung, rata-rata berukuran panjang total 2,54 mm (Imanto \& Melianawati, 2003) dan larva L. argentimaculatus yang berasal dari induk yang sudah didomestikasi berkisar antara 2,17--2,44 mm. Sedangkan larva kerapu bebek (Cromileptes altivelis), kerapu macan (Epinephelus fuscogutattus), dan kerapu batik (E. microdon), masing-masing tercatat berukuran 1,74 mm (Tridjoko et al., 1996); 1,34 \pm $0,053 \mathrm{~mm}$ (Kohno et al., 1990); dan 1,52 $\pm 0,15 \mathrm{~mm}$ (Slamet \& Tridjoko, 1997).

Ukuran kuning telur (yolk) yang dibawa oleh larva napoleon yang baru menetas juga jauh lebih kecil dibandingkan dengan kuning telur larva kakap merah dan larva beberapa jenis kerapu. Larva kakap merah L. sebae membawa kuning telur sebesar $1.808 \times 10^{-4}$ $\mathrm{mm}^{3}$ (Imanto \& Melianawati, 2003), sedangkan pada 


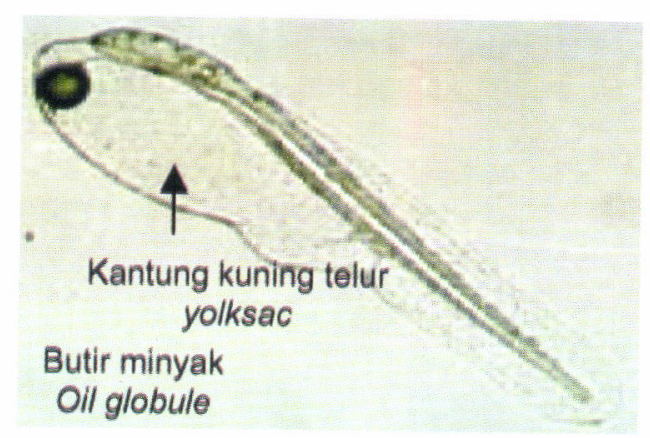

Gambar 1. Larva napoleon baru menetas

Figure 1. Newly hatched napoleon larvae

larva $L$. argentimaculatus ukurannya berkisar antara $1.489 \times 10^{-4} \mathrm{~mm}^{3}$ sampai $1.817 \times 10^{-4} \mathrm{~mm}^{3}$ (Doi \&
Singhagraiawan, 1993). Pada jenis ikan kerapu, kuning telur kerapu bebek sebesar $3.106 \times 10^{-4} \mathrm{~mm}^{3}$ (Tridjoko et al., 1999) dan pada kerapu macan sebesar 1.687,3 x $10^{-4} \mathrm{~mm}^{3}$ (Kohno et al., 1990).

Butir minyak larva napoleon sedikit lebih besar daripada butir minyak yang dibawa oleh larva $L$. sebae sebesar $10.928 \times 10^{-4} \mathrm{~mm}^{3}$ (Imanto \& Melianawati, 2003), namun lebih kecil jika dibandingkan dengan butir minyak larva L. argentimaculatus, kerapu bebek, kerapu macan, maupun beronang (Siganus javus), yang masing-masing berukuran $20,2 \times 10^{-4} \mathrm{~mm}^{3}$ sampai 24,7 x 10-4 $\mathrm{mm}^{3}$ (Doi \& Singhagraiawan, 1993); $48,4 \times 10^{-4} \mathrm{~mm}^{3}$ (Tridjoko et al., 1999); 35,7 × 10-4 $\mathrm{mm}^{3}$ (Kohno et al., 1990); dan 29,0 x 10-4 $\mathrm{mm}^{3}$ (Diani et al., 1990).

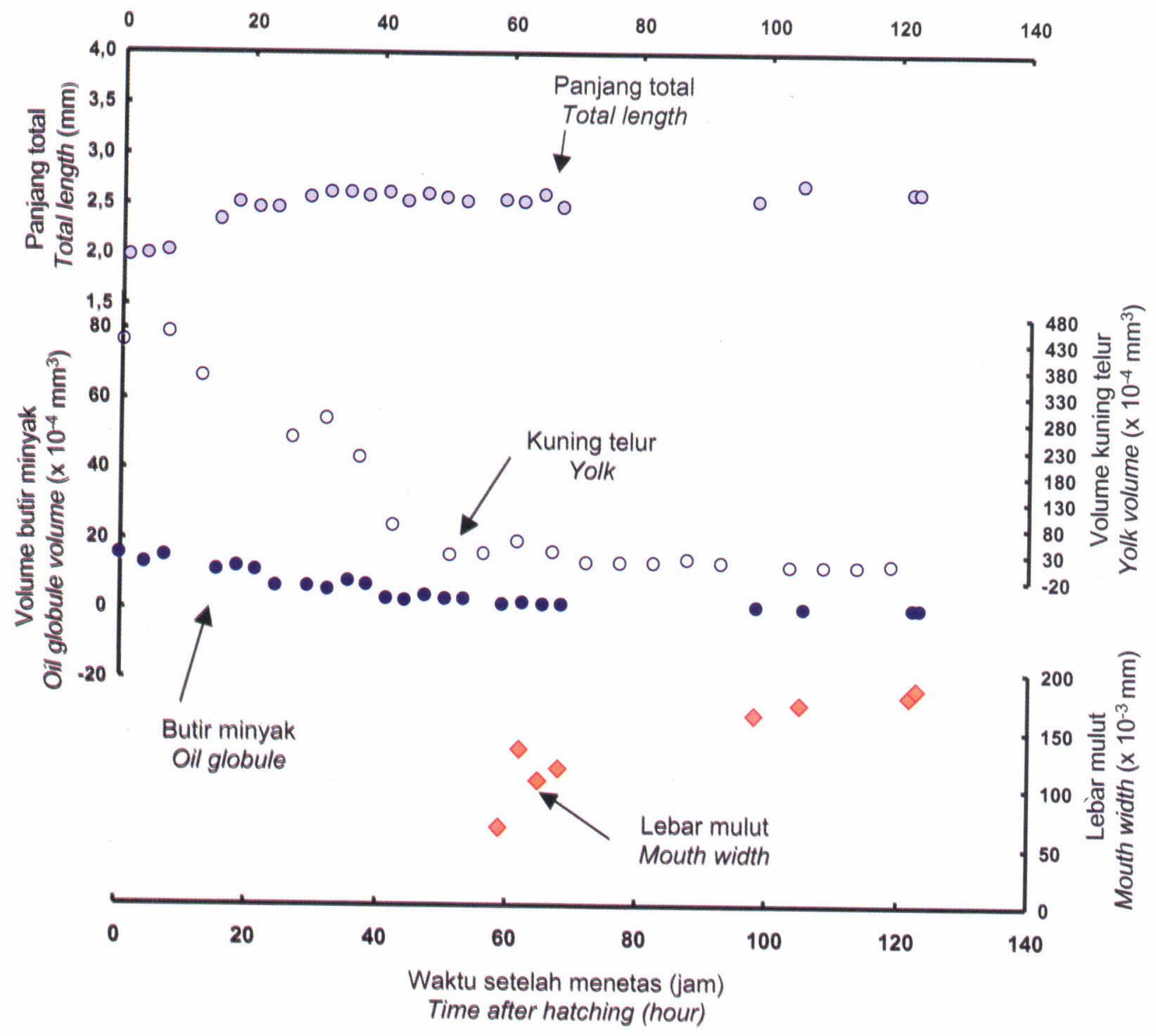

Gambar 2. Performansi pertumbuhan panjang total (TL), penyerapan kuning telur, dan butir minyak serta perkembangan lebar mulut dari larva ikan napoleon

Figure 2. Growth performance in total length (TL), yolk, and oil globule absorption and the development of mouth width of napoleon larvae 
Dengan kondisi sumber endogenous energy yang relatif terbatas seperti tersebut di atas, maka dapat diduga bahwa untuk kegiatan pemeliharaan larva (produksi benih) ikan napoleon akan mengalami tingkat kesulitan yang lebih tinggi dibandingkan pemeliharaan pada larva kakap merah maupun jenis larva kerapu.

Hubungan antara pertumbuhan larva (panjang total), pola penyerapan kuning telur dan butir minyak serta perkembangan lebar mulut larva napoleon yang dipelihara pada kondisi suhu air $29-31^{\circ} \mathrm{C}$ dan salinitas 33-35 ppt dapat dilihat pada Gambar 2.

Dari Gambar 2 terlihat adanya hubungan yang positif antara proses pertumbuhan larva dengan aktivitas penyerapan kuning telur. Hasil pengamatan menunjukkan bahwa pertumbuhan larva dan penyerapan kuning telur berlangsung cepat sejak larva menetas sampai berumur 40 jam setelah menetas (Gambar 3), di mana pada saat itu volume kuning telur berukuran $22,6 \times 10^{-4} \mathrm{~mm}^{3}$ dan penyerapannya mencapai $94,65 \%$. Dari analisis data diketahui bahwa pola penyerapan kuning telur tersebut mengikuti garis regresi eksponensial dengan persamaan $y=566,98 e^{-0,0792 x}$. Yunus et al. (1999) mengemukakan bahwa kuning telur larva ikan napoleon yang berumur satu hari terlihat sudah banyak terserap.

Dalam waktu 40 jam setelah menetas, proses pertumbuhan larva menunjukkan pola pertumbuhan yang menurun sampai umur \pm 68 jam setelah menetas (Gambar 5). Dalam periode waktu tersebut aktivitas penyerapan kuning telur berlangsung lambat, hal ini disebabkan ketersediaan kuning telur pada larva sudah tinggal sedikit dan habis terserap seluruhnya pada \pm 70 jam setelah menetas. Waktu ini relatif lebih cepat dibandingkan penyerapan kuning telur larva kerapu macan E. fuscoguttatus yang baru habis pada 71-87 jam setelah menetas (Kohno et al., 1990).

Berbeda dengan aktivitas penyerapan kuning telur, penyerapan butir minyak larva napoleon berlangsung

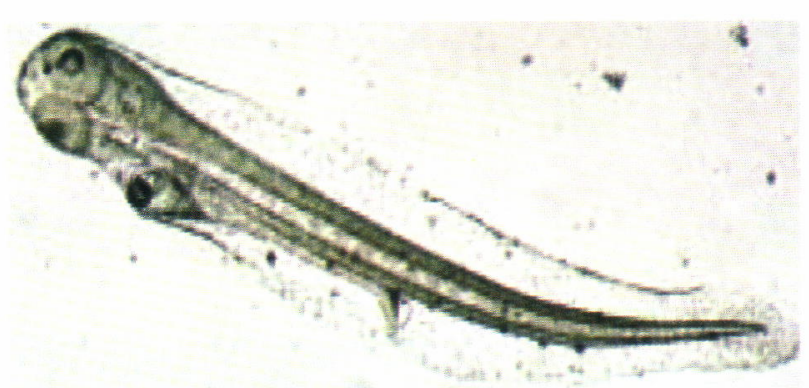

Gambar 3. Larva napoleon 40 jam setelah menetas Figure 3. Napoleon larvae at 40 hours after hatching lambat sampai \pm 35 jam setelah menetas (terserap $49,92 \%$ ). Pendapat senada juga dikemukakan oleh Yunus et al. (1999), yaitu bahwa pada larva umur satu hari penyerapan butir minyaknya masih relatif lambat. Penyerapan berangsur meningkat pada 36 jam setelah menetas sampai 68 jam setelah menetas (Gambar 4), di mana pada waktu tersebut penyerapan dapat mencapai 94,15\%.

Peningkatan penyerapan ini diduga berkaitan dengan mulai terjadinya pigmentasi mata hingga sempurna pada 50 jam setelah menetas. Pada periode ini diperkirakan larva mulai aktif memanfaatkan butir minyak untuk aktivitas geraknya setelah memiliki kemampuan melihat. Setelah itu penyerapan butir minyak kembali berlangsung lambat sampai pada akhir pengamatan (123 jam setelah menetas), di mana pada saat itu butir minyak hanya tersisa sebesar $0,01 \times 10^{-4} \mathrm{~mm}^{3}$ dan penyerapan telah mencapai $99,94 \%$.

Perhitungan regresi garis pertumbuhan dan hasil analisis regresi untuk mengetahui pola pertumbuhan dari larva napoleon ini menghasilkan tiga persamaan garis sebagai berikut: 1) $y=0,2045 \ln (x)+1,8169$; 2) $y=-0,1151 \ln (x)+2,9987 ;$ dan 3) $y=0,2879 \ln (x)$ $+1,2556$. Dari hasil analisis ketiga persamaan garis tersebut menunjukkan adanya dua titik belok (flection point). Garis pertumbuhan hingga titik belok pertama (40,42 jam setelah menetas) memperlihatkan terjadinya pertumbuhan yang cepat pada larva napoleon, di mana hal ini berkaitan dengan terjadinya penggunaan energi yang berasal dari kuning telur untuk pertumbuhan. Setelah titik belok tersebut, terjadi garis pertumbuhan larva yang menurun, di mana hal ini disebabkan telah berkurangnya energi yang berasal dari kuning telur sehingga butir minyak dan sebagian jaringan tubuh larva (body tissue) dipergunakan untuk mencukupi kebutuhan energinya (Rogers \& Westin, 1981 dalam Kohno et al., 1990) selama larva belum mampu untuk mengambil energi dari luar tubuhnya. Di samping itu juga dipergunakan untuk pembentukan

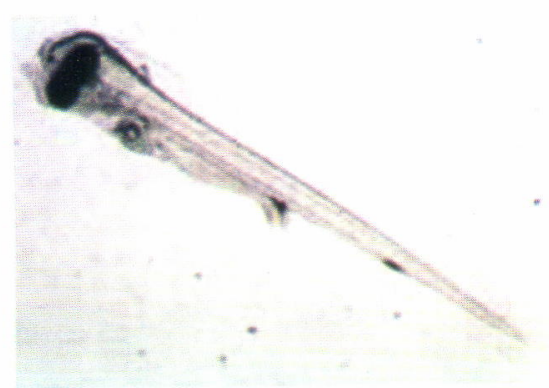

Gambar 4. Larva napoleon 68 jam setelah menetas Figure 4. Napoleon larvae at 68 hour after hatching 


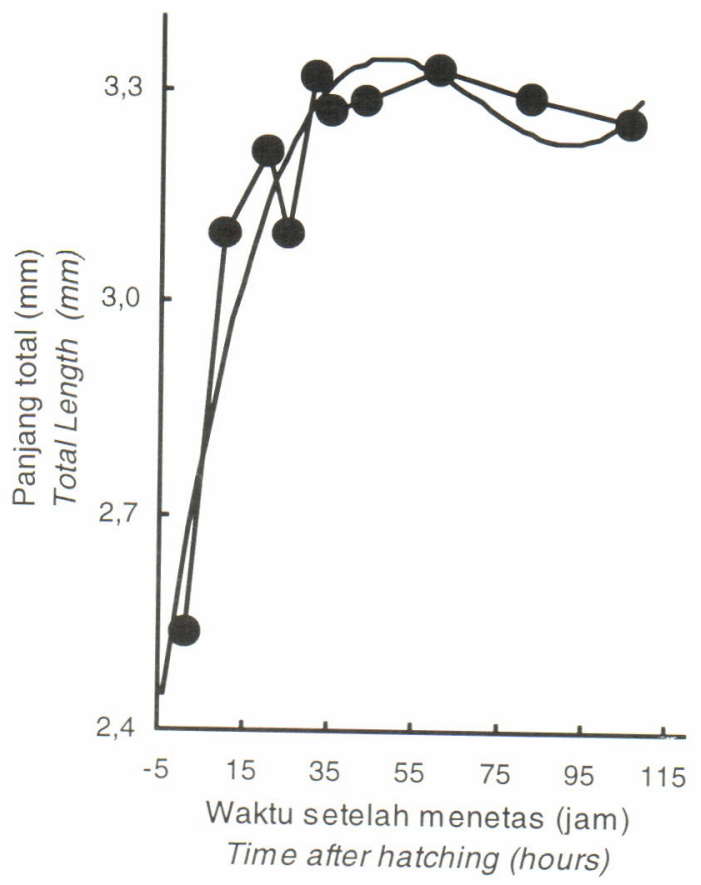

Gambar 5. Pola pertumbuhan larva napoleon

Figure 5. Growth performance of napoleon larvae

kelengkapan morfologis larva yang pada saat itu masih belum sempurna. Titik belok berikutnya terjadi pada 75,59 jam setelah menetas, di mana garis pertumbuhan larva menunjukkan terjadinya pertumbuhan yang positif. Hubungannya dengan kelengkapan morfologis larva (Gambar 6), adalah bahwa pigmentasi mata dan bukaan mulut yang telah sempurna pada 59 jam setelah menetas, menyebabkan butir minyak tidak lagi digunakan untuk proses pembentukan kelengkapan morfologis, tetapi yang masih tersisa digunakan sebagai sumber energi untuk pertumbuhan. Pada periode ini terlihat pula bahwa sesungguhnya larva telah mampu menggunakan sumber energi luar yang berasal dari pakan (exogenous energy) tepatnya mulai 62 jam setelah menetas, di samping masih tetap memanfaatkan sisa sumber energi dari dalam (endogenous energy) yaitu sisa dari butir minyak, baik dalam proses pertumbuhan maupun untuk aktivitas gerak.

Data perkembangan morfologis larva ikan napoleon ditampilkan pada Gambar 6, dan dari gambar tersebut dapat dilihat bahwa awal pigmentasi mata mulai terjadi pada 36 jam setelah menetas. Lebar mulut larva meningkat ukurannya seiring dengan meningkatnya umur larva, di mana pada umur 3 hari lebar mulut larva tercatat $133 \mu \mathrm{m}$ (62 jam setelah menetas), kemudian meningkat menjadi $163 \mu \mathrm{m}$ dan $178 \mu \mathrm{m}$ pada larva umur 4 hari (98 jam setelah menetas) dan umur 5 hari (122 jam setelah menetas).

Dari Gambar 6 juga diketahui bahwa periode waktu antara 59-70 jam setelah menetas merupakan waktu kritis bagi larva untuk mendapatkan energi dari luar (exogenous energy) karena pada kisaran waktu tersebut pigmentasi mata sempurna, mulut telah membuka sempurna (59 jam setelah menetas) dan saat habisnya kuning telur (70 jam setelah menetas)

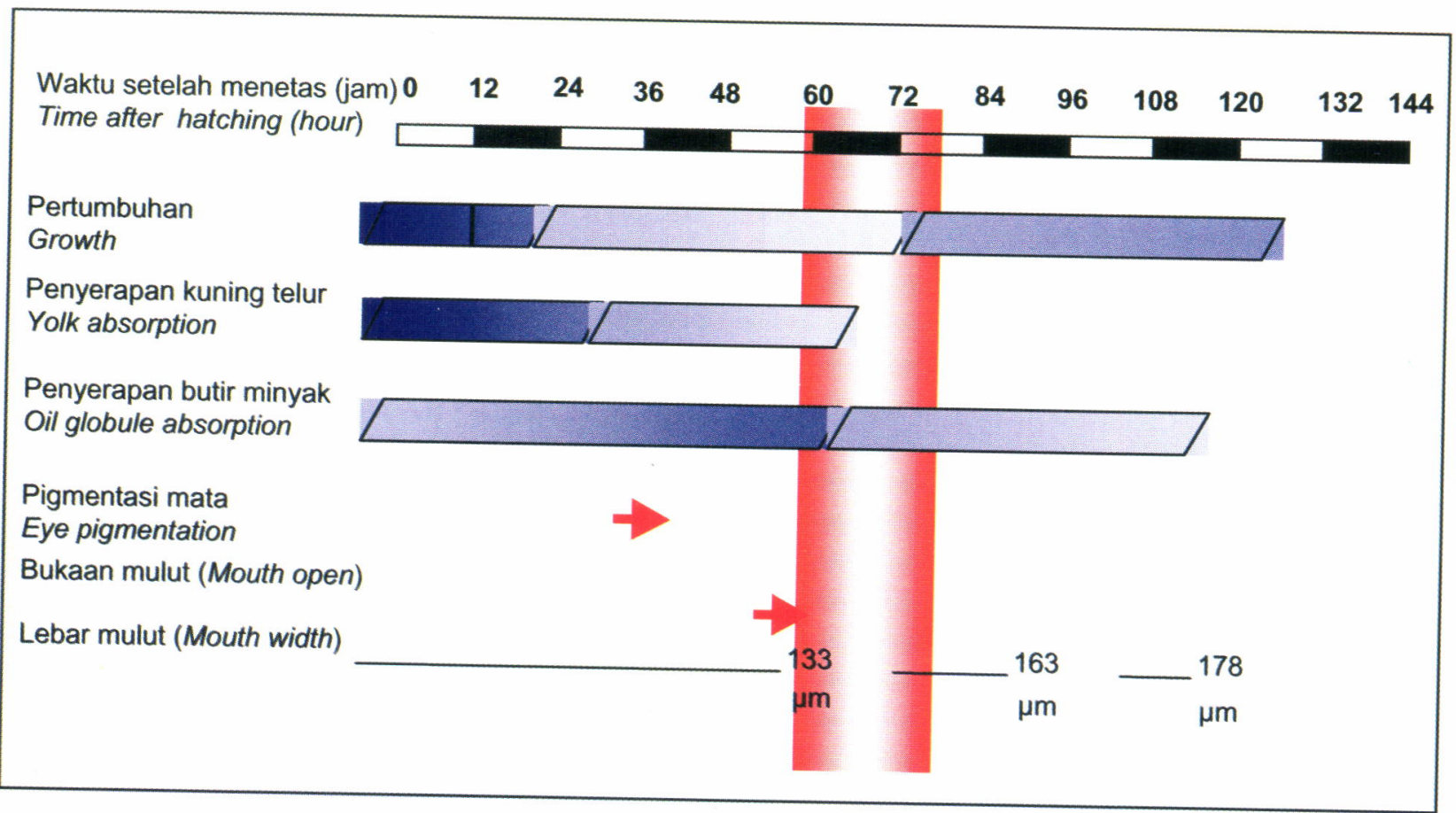

Gambar 6. Perkembangan morfologis larva ikan napoleon

Figure 6. Morphology development of napoleon fish larvae 


\section{KESIMPULAN DAN SARAN}

Perkembangan stadia awal larva awal ikan napoleon (Cheilinus undulatus) terjadi dengan cepat pada 40 jam pertama setelah menetas dan berkaitan erat dengan penggunaan endogenus energy yang berasal dari kuning telur. Pergerakan organ dan tubuh lebih berkaitan dengan penggunaan energi yang berasal dari butir minyak. Kemampuan larva mulai memangsa diperkirakan terjadi pada 62 jam setelah menetas, sehingga mulai terjadi peningkatan pertumbuhan lagi 75 jam setelah menetas (second flection point), di mana masa kritis pertukaran sumber energi (endogenus energy -> exogenous energy) terjadi 5970 jam setelah menetas.

Sediaan pakan awal untuk larva ikan napoleon harus memiliki ukuran yang kecil, tepatnya kurang dari 120 mikron, sesuai dengan bukaan mulut larva yang berukuran 133 mikron, dan sebaiknya disiapkan mulai 60 jam setelah menetas. Penyediaan intensitas cahaya yang penting untuk mendukung larva dalam mengambil mangsa, masih memerlukan penelitian lebih lanjut.

\section{DAFTAR PUSTAKA}

Anonim. 1995. Petunjuk Pelaksanaan Pembinaan dan Pengelolaan Ikan Napoleon Wrase (Cheilinus undulatus). Direktur Bina Sumber Hayati, Direktorat Jenderal Perikanan. Jakarta. 24 pp.

Diani, S., B. Slamet, P.T. Imanto, and H. Kohno. 1990. Resorption of endogenous nutrition and initial feeding of the rabbitfish, Siganus javus. Bull. Pen. Perikanan, special edition 1: 83-88.

Doi, M. and Singhagraiwan. 1993. Biology and culture of the red snapper, Lutjanus argentimaculatus. The Research Project of Fishery Resource Development in the Kingdom of Thailand. The Eastern marine fisheries development center (EMDEC), Department of fisheries, ministry of agriculture and cooperatives, Thailand. $51 \mathrm{pp}$.

Kohno, H., S. Hara, M. Duray, and A. Gallego. 1988. Transition from endogenous to exogenous nutrition sources in larval rabbitfish Siganus guttatus. Nippon Suisan Gakkaishi, 54(7): 1,083--1,091.

Kohno, H., S. Hara, and Y. Taki. 1986. Early larval development of the seabass Lates calcarifer with emphasis on the transition of energy sources. Bulletin of the Japanese Society of Scientific Fisheries, 52(10): 1,719-1,725 .

Kohno, H., S. Diani, P. Sunyoto, B. Slamet, and Philip T.I. 1990. Early development events associated with changeover of nutrient sources in the grouper, Epinephelus fuscoguttatus, larvae. Bull. Pen. Perikanan, special edition 1: 51--64.

Imanto, P.T. dan R. Melianawati. 2003. Perkembangan awal larva kakap merah, Lutjanus sebae. J. Pen. Per. Indonesia IX (1): 11--19.

Slamet, B. dan Philip T.I. 1997. Pengamatan beberapa aspek biologi ikan napoleon, Cheilinus undulatus. Prosiding Seminar Biologi XIV dan Kongres Nasional Biologi XI Depok. p. 49--53.

Slamet, B. dan Tridjoko. 1997. Pengamatan pemijahan alami, perkembangan embrio, dan larva ikan kerapu batik, Epinephelus microdon dalam bak terkontrol. J. Pen. Per. Indonesia III (4):40--50.

Slamet, B., Hersapto, dan Tridjoko, 1999. Pematangan induk ikan napoleon, Cheilinus undulatus, dengan pemberian jenis pakan segar yang berbeda. Prosiding Seminar Nasional Penelitian dan Diseminasi Teknologi Budi Daya Laut dan Pantai Jakarta 2 Desember 1999, p. 253--256.

Tridjoko, B. Slamet, D. Makatutu, dan K. Sugama. 1996. Pengamatan pemijahan dan perkembangan telur ikan kerapu bebek Cromileptes altivelis pada bak secara terkontrol. J. Pen. Per. Indonesia II (2): 55--62.

Tridjoko, B. Slamet, T. Aslianti, Wardoyo, S. Ismi, J.H. Hutapea, K.M. Setiawati, I. Rusdi, D. Makatutu, A. Prijono, T. Setiadharma, M. Hirokazu, and K. Shigeru. 1999. Research and Development: The Seed Production Technique of Humpback Grouper, Cromileptes altivelis. JICA and Gondol Research station for Coastal Fisheries, $55 \mathrm{pp}$.

Yunus, T. Ruchimat, B. Slamet, dan S. Ismi. 1999. Pengamatan perkembangan embrio dan larva ikan napoleon (Cheilinus undulatus) dalam Sudradjat et al., 1999. Prosiding Seminar Nasional Penelitian dan Diseminasi Teknologi Budi Daya Laut dan Pantai, Jakarta 2 Desember 1999, p. 226--231. 


\title{
PENGARUH ASAM LEMAK ESENSIAL TERHADAP SINTASAN DAN VITALITAS LARVA KERAPU BEBEK, Cromileptes altivelis
}

\author{
Ketut Suwirya, Wardoyo, Nyoman Adiasmara Giri, dan Muhammad Marzuqi
}

\begin{abstract}
ABSTRAK
Asam lemak tak jenuh rantai panjang n-3 (n-3 HUFA) adalah esensial bagi ikan-ikan laut. Kebutuhan asam lemak n-3 HUFA pada ikan berbeda menurut jenis dan ukuran ikan. Percobaan ini dilaksanakan untuk mengetahui kebutuhan n-3 HUFA pada larva ikan kerapu bebek. Larva kerapu bebek dipelihara dalam bak polikarbonat $200 \mathrm{~L}$ dengan kepadatan 10 ekor/L dan ditambahkan Nannochloropsis sp. pada kepadatan $10^{4} \mathrm{sel} / \mathrm{mL}$ untuk mempertahankan warna media pemeliharaan menjadi hijau. Rotifer yang baru dipanen dimasukkan dalam wadah 100 $\mathrm{L}$ dengan kepadatan 500 individu/mL dan diberikan emulsi $\mathrm{n}-3$ HUFA: asam oleik dengan perbandingan 2:1 (A), 1:1 (B), 1:2 (C), dan Nannochloropsis sp. (D) selama 4 jam. Pemberian awal, rotifera yang diperkaya dilaksanakan pada hari kedua setelah larva menetas dengan kepadatan 5 individu/mL. Untuk selanjutnya rotifera yang telah diperkaya ditambahkan ke dalam bak pemeliharaan larva dengan kepadatan 10 individu/mL. Percobaan dilaksanakan selama 20 hari dengan 4 perlakuan dan tiga ulangan. Hasil percobaan menunjukkan bahwa kandungan $n-3$ HUFA dalam rotifer mempengaruhi sintasan dan vitalitas larva $(P<0,05)$. Pengkayaan rotifer dengan emulsi n-3 HUFA dan asam lemak oleik dengan perbandingan 2:1 (A) dan 1:1 (B) memberikan sintasan dan vitalitas larva yang lebih baik dibandingkan dengan perlakuan yang lain dan kandungan n-3 HUFA rotifer dari pengkayaan tersebut adalah $12,90 \%--17,66 \%$ dari total lemak. Pertumbuhan larva yang diberi pakan dengan kadar n-3 HUFA berbeda mempunyai pertumbuhan yang sama sampai umur larva 20 hari.
\end{abstract}

ABSTRACT: Effect of essential fatty acid on survival and vitality of humpback grouper (Cromileptes altivelis) larvae. By: Ketut Suwirya, Wardoyo, Nyoman Adiasmara Giri, and Muhammad Marzuqi

A group of n-3 HUFA is essential for marine fish. Requirement of n-3 HUFA for the fish depends on species and size of fish. This experiment was conducted to know the requirement of $n-3$ HUFA on larvae of humpback grouper. Humpback grouper larvae were reared in $200 \mathrm{~L}$ polyetiline tank with density of 10 individual/L with the addition of Nannochloropsis sp. to kept the color of media green. Harvested rotifers were kept in $100 \mathrm{~L}$ tank in a density of 500 individual per $m L$. They were fed emulsion $n-3$ HUFA : oleic acid with ratio 2:1 (A), 1:1 (B), 1:2 (C), and Nannochloropsis sp. (D) for 4 hours. First feeding of enriched rotifer was done in the second day after hatching in a density of 5 individual per $\mathrm{mL}$, while for the next feeding, was 10 individual enriched rotifer per $\mathrm{mL}$. This experiment was done for 20 days with 4 treatments and 3 replications. The result of experiment showed that $n-3$ HUFA content of rotifer affected survival and vitality of larvae $(P<0.05)$. Enriched rotifer by emulsion $n-3$ HUFA: oleic acid with ratio $2: 1(A)$ and $1: 1(B)$ had better survival and vitality than other treatments in early stage of humpback grouper. The content of $n-3$ HUFA in rotifer enriched by $A$ and $B$ was $12.90 \%-17.66 \%$ in total lipid. Larvae fed with rotifer in different content of $n-3$ HUFA had same growth until rearing 20 days old.

KEYWORDS: humpback grouper, larvae, n-3 HUFA, survival, vitality

\section{PENDAHULUAN}

Ikan kerapu bebek merupakan salah satu komoditas perikanan yang bernilai tinggi, terutama di pasar Asia. Didorong oleh permintaan pasar yang meningkat mengakibatkan usaha penangkapan ikan ini di alam semakin meningkat sehingga populasinya cenderung menurun. Untuk mengantisipasi hal ini maka perlu didorong usaha budi dayanya. Keberhasilan dalam memijahkan beberapa spesies ikan seringkali tidak segera diikuti oleh keberhasilan dalam pengembangan teknologi pemeliharaan larvanya sampai menghasilkan benih. Secara umum larva ikanikan laut berukuran sangat kecil dengan ukuran mulut yang kecil pula, termasuk ikan kerapu (Kohno et al., 1997). Keadaan ini menyulitkan dalam manajemen

Peneliti pada Balai Besar Riset Perikanan Budidaya Laut, Gondol 
pakan, di mana secara fisik diperlukan pakan berukuran kecil, seperti rotifer tipe-SS. Rotifera dewasa tipe-S dan tipe-L masih terlalu besar untuk stadia awal larva dari kebanyakan spesies ikan kerapu (Lim, 1993).

Akhir-akhir ini teknologi pembenihan ikan kerapu bebek telah berhasil dikembangkan dan telah berhasil memproduksi benih untuk keperluan budi daya, namun produksinya masih berfluktuasi. Oleh karena itu mulai pada tingkat larva perlu diperhatikan faktor-faktor yang mempengaruhinya.

Salah satu faktor yang prinsip dan berpengaruh adalah nilai nutrisi organisme pakan seperti kandungan eicosapentaenoic acid (EPA) dan docosahexaenoic acid (DHA) dari rotifera serta artemia. Kedua asam lemak tersebut dimasukkan dalam kelompok $n$-3 high unsaturated fatty acid ( $n-3$ HUFA) yang merupakan asam lemak esensial (EFA) bagi ikan-ikan laut (Watanabe et al., 1978). Laporan penelitian asam lemak esensial pada ikan laut menunjukkan bahwa nilai DHA adalah lebih penting daripada EPA untuk larva yang sama seperti ikan red sea bream, yellowtail, dan striped jack (Watanabe, 1993). N-3 HUFA merupakan asam lemak esensial bagi kerapu bebek, hal ini dapat dilihat dari penurunan asam lemak tersebut lebih tinggi pada kelas lemak nonpolar dibandingkan dengan kelas lemak polar pada larva dari fase neurula sampai larva umur 3 hari, namun asam lemak tersebut meningkat baik pada lemak polar maupun pada lemak nonpolar setelah larva diberi pakan berupa rotifera (Suwirya et al., 2002). Hal tersebut menunjukkan bahwa asam lemak esensial pada larva berasal dari pakan yang diberikan.

Pengkayaan rotifera dan naupli artemia dengan asam lemak esensial telah dilakukan secara luas untuk meningkatkan nilai nutrisinya. Beberapa produk dan prosedur pengkaya telah dikembangkan seperti penggunaan mikroalga tertentu, produk mikrokapsul, dan emulsi lemak.

Percobaan ini dilaksanakan dengan memperkaya rotifera secara emulsi pada beberapa leveln-3 HUFA dan Nannochloropsis sp. untuk pakan larva ikan kerapu bebek, Cromileptes altivelis pada tahap awal. Selanjutnya profil asam lemak dilihat dari rotifera yang diperkaya dan pada larva ikan pada akhir percobaan. Tujuan dari percobaan ini adalah untuk melihat pengaruh kadar n-3 HUFA dalam rotifera terhadap pertumbuhan dan sintasan larva.

\section{BAHAN DAN METODE}

Rotifera yang baru dipanen dimasukkan ke dalam wadah $100 \mathrm{~L}$ dengan kepadatan 500 individu/mL dan diberikan emulsi n-3 HUFA: asam oleik dengan perbandingan $2: 1$ (A), $1: 1$ (B), 1:2 (C), dan
Nannochlorpsis sp. (D). Adapun komposisi asam lemak dari emulsi n-3 HUFA adalah sebagai berikut: asam miristik (14:0) 3,5\%; asam palmitat (16:0) 23,5\%; asam palmitoloik (16:1n-9) 3,9\%; asam oleik (18:0) 15,4\%; asam linoleat (18:3n-3) 3,6\%; asam arachidonat (20:4n-6) 3,2\%; EPA (20:5n-3) 9,1\%; dan DHA (22:6n-3) 30,9\%. Sebanyak 15 g sumber lemak dari setiap perlakuan dicampur dengan $20 \mathrm{~g}$ kuning telur ayam dan $5 \mathrm{~g}$ ragi roti (Saccaromyces cereviseae) dengan menggunakan alat homogenizer. Campuran tersebut merupakan dosis pengkaya $100 \mathrm{~L}$ dengan kepadatan rotifera 500 ind./mL. Nannochloropsis sp. diberikan pada kepadatan $10^{6} / \mathrm{mL}$ sebagai kontrol (D). Pengkayaan dilaksanakan selama 4 jam pada suhu $29^{\circ} \mathrm{C}-30^{\circ} \mathrm{C}$ dengan aerasi yang kuat. Prosedur pengkayaan rotifera ini mengikuti sistem pengkayaan yang dilakukan oleh Waspada et al. (1991).

Larva kerapu bebek dipelihara dalam bak polikarbonat $200 \mathrm{~L}$ dengan kepadatan 10 ekor per $\mathrm{L}$ dan ditambahkan Nannochloropsis sp. pada kepadatan $10^{4} \mathrm{sel} / \mathrm{mL}$ untuk mempertahankan warna media pemeliharaan menjadi hijau. Pemberian rotifera yang diperkaya awal dilaksanakan pada hari kedua setelah larva menetas dengan kepadatan 5 individu per $\mathrm{mL}$. Untuk selanjutnya rotifera yang telah diperkaya ditambah ke dalam bak pemeliharaan larva dengan kepadatan 10 individu/mL. Percobaan dilaksanakan selama 20 hari dengan 4 perlakuan dan tiga ulangan. Peubah yang diamati adalah panjang dan sintasan larva pada akhir percobaan. Di samping itu uji vitalitas larva dilaksanakan pada akhir percobaan dengan cara memasukkan 20 ekor larva ke dalam baker ukuran $1 \mathrm{~L}$ kemudian diisi air laut yang telah disaring dengan saringan 1 mikron. Sintasan larva diamati setiap 2 jam. Semua peubah diuji dan dianalisis menggunakan analisis ragam dan uji LSD pada taraf nyata 95\% (Steel \& Torrie, 1980).

Rotifera yang telah diperkaya dan semua larva dari masing-masing perlakuan diambil untuk analisis komposisi asam lemak. Komposisi asam lemak disajikan secara deskriptif.

\section{HASIL DAN BAHASAN}

Komposisi asam lemak rotifera yang diperkaya emulsi n-3 HUFA: oleik dengan perbandingan 2:1 (A), 1:1 (B), 1:2 (C), dan Nannochloropsis sp. (D) disajikan pada Tabel 1. Kandungan n-3 HUFA rotifera yang diperkaya dengan $\mathrm{A}, \mathrm{B}, \mathrm{C}$, dan $\mathrm{D}$ berturut-turut adalah $17,66 \% ; 12,90 \% ; 6,42 \%$; dan 5,75\%. Hasil analisis menunjukkan bahwa semakin tinggi kadar n-3 HUFA dalam emulsi yang diberikan pada rotifera akan meningkatkan kadar n-3 HUFA rotifera. Hal ini menunjukkan bahwa nilai nutrisi rotifera dapat ditingkatkan dengan cara pengkayaan. Menurut Watanabe et al. (1983), nilai gizi pakan alami untuk 
Tabel 1. Komposisi asam lemak rotifera (\%) setelah diperkaya selama 4 jam

Table 1. Fatty acid composition of rotifer (\%) was enriched for 4 hours

\begin{tabular}{lrrrr}
\hline \multirow{2}{*}{$\begin{array}{c}\text { Asam lemak (Fatty acid) } \\
\text { Asam miristik (Myristic acid) (14:0) }\end{array}$} & \multicolumn{3}{c}{$\begin{array}{c}\text { Komposisi asam lemak rotife ra (\%) } \\
\text { Fatty acid composition of rotifer (\%) }\end{array}$} \\
\cline { 2 - 5 } & A & B & C & D \\
\hline Asam palmitat (Palmitat acid) (16:0) & 5.54 & 4.05 & 3.71 & 2.09 \\
Asam palmitoleik (Palmitoleic acid) (16:1n-9) & 26.96 & 29.68 & 29.87 & 20.16 \\
Asam oleik (Oleic acid) (18:1n-9) & 16.78 & 18.54 & 23.42 & 11.17 \\
Asam linolenat (Linolenic acid) (18:3n-3) & 10.82 & 13.54 & 16.51 & 10.17 \\
Asam arachidonat (Arachidonate acid) (20:4n-6) & 20.60 & 20.15 & 21.05 & 40.17 \\
EPA (20:5n-3) & 1.24 & 0.28 & 2.02 & 3.79 \\
DHA (22:6n-3) & 7.88 & 5.09 & 2.56 & 2.55 \\
NN* & 9.78 & 7.81 & 3.86 & 3.20 \\
\hline \multicolumn{1}{c}{ Total n-3 HUFA } & 0.40 & 0.86 & 0.71 & 6.70 \\
\hline
\end{tabular}

*)Asam lemak yang tidak dapat diidentifikasi (Unidentified fatty acid)

$\mathrm{A}=$ Rotifera diperkaya dengan emulsi n-3 HUFA: asam oleik (2:1) $(A=$ enriched rotifer by $n-3$ HUFA emulsion : oleic acid (2:1))

$\mathrm{B}=$ emulsi $\mathrm{n}-3$ HUFA : asam oleik (1:1) $(B=n-3$ HUFA emuision : oleic acid $(1: 1))$

$\mathrm{C}=$ emulsi n-3 HUFA : asam oleik (1:2), dan ( $C=n-3$ HUFA emulsion : oleic acid (1:2), and

$\mathrm{D}=$ Nannochloropsis sp.

ikan dapat dilihat dari kandungan asam lemak esensialnya.

Ukuran panjang total larva ikan kerapu bebek pada akhir percobaan yang diberi pakan rotifera dengan kandungan $n-3$ HUFA yang berbeda tidak berpengaruh sampai larva berumur 20 hari $(P>0,05)$. Namun rotifera dengan kandungan n-3 HUFA berbeda berpengaruh nyata terhadap sintasan dan vitalitas larva kerapu bebek. Larva yang diberi rotifera dengan kandungan n-3 HUFA lemaknya 12,90\%--17,66\% mempunyai sintasan dan vitalitas yang lebih tinggi dibandingkan dengan larva yang diberi pakan rotifer dengan kandungan n-3 HUFA lemaknya 5,75\%--6,42\% (Tabel 2). Hal ini menunjukkan bahwa kandungan n-3 HUFA dalam rotifera perlu mendapat perhatian dalam pemeliharaan larva kerapu bebek.

Hasil penelitian ini didukung oleh beberapa laporan yang dilaksanakan pada ikan-ikan laut bahwa kekurangan n-3 HUFA mengakibatkan tingkat kematian yang tinggi dan pertumbuhan yang lambat, serta tidak sempurnanya pembentukan dan fungsi gelembung renang pada larva ikan (Sorgeloos et al.,

Tabel 2. Panjang total, sintasan, dan vitalitas larva yang diberi pakan rotifera dengan kandungan n-3 HUFA berbeda

Table 2. Total length, survival rate, and vitality of humpback grouper larvae feed different rotifer which contain different $n-3$ HUFA

\begin{tabular}{cccc}
\hline $\begin{array}{c}\text { Rotifera } \\
\text { Rotifer }\end{array}$ & $\begin{array}{c}\text { Panjang total larva pada } \\
\text { akhir percobaan } \\
\text { Total lenght of larvae at the } \\
\text { end of experiment }(\mathrm{mm})\end{array}$ & $\begin{array}{c}\text { Sintasan } \\
\text { Survival rate } \\
(\%)\end{array}$ & $\begin{array}{c}\text { Vitalitas larva dalam 16 jam } \\
\text { Vitality of larvae in 16 hours } \\
\text { (\%) }\end{array}$ \\
\hline A & $4.39 \pm 0.27^{\mathrm{a}}$ & $24.38 \pm 2.02^{\mathrm{b}}$ & $63.3 \pm 2.5^{\mathrm{c}}$ \\
B & $4.18 \pm 0.40^{\mathrm{a}}$ & $24.97 \pm 58^{\mathrm{b}}$ & $76.6 \pm 5.5^{\mathrm{c}}$ \\
C & $4.39 \pm 0.18^{\mathrm{a}}$ & $15.78 \pm 3.67^{\mathrm{a}}$ & $50.0 \pm 9.1^{\mathrm{b}}$ \\
D & $4.26 \pm 3.60^{\mathrm{a}}$ & $16.24 \pm 2.13^{\mathrm{a}}$ & $25.3 \pm 22.5^{\mathrm{a}}$ \\
\hline
\end{tabular}

- Nilai dengan huruf yang sama dalam kolom tidak berbeda nyata $P>0,05$ ) (mean with same superscript in columns are not statistically different $(P>0.05))$ 
1988; Webster \& Lovel, 1990; dan Koven et al., 1990). Asam lemak tersebut sangat dibutuhkan pada stadia awal perkembangan larva untuk mendukung perkembangan organ visual dan syaraf secara normal (Sargent et al., 1993). Kebutuhan n-3 HUFA ikan adalah bergantung pada jenis dan ukuran ikan. Kebutuhan n-3 HUFA larva ikan gilthead sea bream adalah 2,05\%--2,16\% (Salhi et al., 1994), yuwana ikan red drum adalah 0,5\%--1,0\% (Lochmann \& Galtin, 1993), ikan Korean rockfish dengan bobot $5,9 \mathrm{~g}$ adalah sekitar 0,9\% (Lee et al., 1993), dan 1,4\% untuk yuwana kerapu bebek (Suwirya et al., 2001).

Komposisi asam lemak dari total lemak larva dengan jelas merupakan refleksi dari komposisi asam lemak rotifera (Tabel 3). Hasil analisis asam lemak larva kerapu bebek menunjukkan bahwa peningkatan kandungan n-3 HUFA rotifera yang diberikan pada larva menunjukkan kandungan n-3 HUFA pada lemak larva meningkat secara proporsional yaitu larva yang diberi rotifera dengan kandungan n-3 HUFA dalam lemaknya $12,90 \%--17,66 \%$ (Tabel 1), maka kadar n-3 HUFA dalam lemak larva adalah 15,90\%--20,06\% (Tabel 3). Sedangkan larva yang diberi rotifera dengan kandungan n-3 HUFA dalam lemaknya $5,75 \%$ sampai $6,42 \%$ (Tabel 1), maka kadar n-3 HUFA dalam lemak larva berkisar 9,75\%--12,42\% (Tabel 3). Pola akumulasi n-3 HUFA pada larva kerapu bebek nampaknya mendekati dari pola yang terjadi pada larva ekor kuning (Furuita et al., 1996) dan benih ikan striped jack (Takeuchi et al., 1992).

Tabel 3 menunjukkan bahwa larva kerapu bebek hanya mempunyai kemampuan yang terbatas untuk menyintesis $n-3$ HUFA dari asam lemak $n-3$ rantai karbon yang lebih pendek, hal ini sesuai dengan hasil laporan Owen et al. (1975). Asam lemak n-3 HUFA seperti 20:5n-3 (EPA) dan 22:6n-3 (DHA) merupakan

Tabel 3. Komposisi asam lemak (\%) larva kerapu bebek yang diberi rotifera dengan beda pengkayaan

Table 3. Fatty acid composition (\%) of humpback grouper larvae feed rotifer with different enrichment

\begin{tabular}{|c|c|c|c|c|}
\hline \multirow{2}{*}{$\begin{array}{l}\text { Asam lemak } \\
\text { Fatty acid }\end{array}$} & \multicolumn{4}{|c|}{$\begin{array}{l}\text { Komposisi asam lemak (\%) larvae kerapu bebek } \\
\text { Fatty acid composition (\%) of humpback grouper }\end{array}$} \\
\hline & $A^{1}$ & $B^{1}$ & $c^{1}$ & $D^{1}$ \\
\hline Asam miristik (Myristic acid) (14:0) & 5.54 & 4.05 & 3.71 & 2.09 \\
\hline Asam palmitat (Palmitat acid) (16:0) & 26.96 & 29.68 & 29.87 & 20.16 \\
\hline Asam palmitoleik (Palmitoleic acid) (16:1n-9) & 14.78 & 18.54 & 20.42 & 11.17 \\
\hline Asam oleik (Oleic acid) (18:1n-9) & 9.82 & 11.54 & 12.51 & 10.17 \\
\hline Asam linolenat (Linolenic acid) $(18: 3 n-3)$ & 18.60 & 19.15 & 21.05 & 36.17 \\
\hline Asam arachidonat (Arachidonate acid) $(20: 4 n-6)$ & 1.24 & 0.28 & 2.02 & 3.79 \\
\hline EPA $(20: 5 n-3)$ & 10.88 & 7.09 & 5.56 & 4.55 \\
\hline DHA (22:6n-3) & 11.78 & 9.81 & 6.86 & 5.20 \\
\hline $\mathrm{NN}^{*}$ & 0.40 & 0.86 & 0.71 & 6.70 \\
\hline Total n-3 HUFA & 22.06 & 15.90 & 12.42 & 9.75 \\
\hline
\end{tabular}

*) Asam lemak yang tidak dapat diidentifikasi (unidentified fatty acid)

${ }^{1}$ Larva diberi rotifera (lihat Tabel 1) (larvae fed rotifer (see Table 1))

Tabel 4. Kualitas air selama percobaan

Table 4. Water quality during the experiment

\begin{tabular}{lcccc}
\hline \multirow{2}{*}{$\begin{array}{c}\text { Parameter } \\
\text { Parameters }\end{array}$} & \multicolumn{4}{c}{ Bahan pengkaya (Enrichment material) } \\
\cline { 2 - 5 } & A & B & C & D \\
\hline $\mathrm{pH}$ & $8.10--8.27$ & $8.15--8.25$ & $8.03--8.31$ & $8.16--8.26$ \\
Salinitas (Salinity) & $33--34$ & $33--34$ & $33--34$ & $33--34$ \\
Suhu (Temperature) $)(\%)$ & $27--29$ & $27--29$ & $27--29$ & $27--29$ \\
$\mathrm{NO}_{2}(\mathrm{mg} / \mathrm{L})$ & $0.03--0.05$ & $0.02--0.05$ & $0.04--0.05$ & $0.02--0.05$ \\
$\mathrm{PO}_{4}(\mathrm{mg} / \mathrm{L})$ & $0.23--1.68$ & $0.31--1.25$ & $0.30--1.63$ & $0.30--1.65$ \\
$\mathrm{NO}_{3}(\mathrm{mg} / \mathrm{L})$ & $0.31--0.38$ & $0.31--0.36$ & $0.31--0.36$ & $0.31--0.36$ \\
$\mathrm{NH}_{3}(\mathrm{mg} / \mathrm{L})$ & $0.26--0.38$ & $0.27--0.38$ & $0.28--0.39$ & $0.26--0.49$ \\
\hline
\end{tabular}


asam lemak esensial bagi kebanyakan ikan laut (Yano \& Fujii, 1975; Fujita et al., 1980; Watanabe et al., 1983; Izquierdo et al., 1989; Webster \& Lovell, 1990; Suwirya et al., 2001), sehingga untuk pemenuhan kebutuhannya diperoleh dari pakan.

Hasil pengamatan kualitas air menunjukkan bahwa suhu, salinitas, $\mathrm{pH}$, nitrit, dan amonia masing-masing adalah dalam kisaran $27--29^{\circ} \mathrm{C}$; 33--34 ppt.; 8,10-8,27; 0,02--0,05 mg/L; 0,26--0,49 mg/L (Tabel 4). Selama masa pemeliharaan larva ikan kerapu bebek, kualitas air masih berada dalam kisaran aman bagi sintasan larva, hal ini sesuai dengan hasil pengamatan Yunus et al. (2001) pada pemeliharaan larva kerapu batik. Kematian larva ikan penelitian selama pemeliharaan diduga bukan karena pengaruh media pemeliharaan, namun diduga karena pengaruh perlakuan yaitu kandungan n-3 HUFA dalam rotifera.

\section{KESIMPULAN}

Kandungan n-3 HUFA dalam rotifera mempengaruhi sintasan dan vitalitas larva ikan kerapu bebek, Cromileptes altivelis. Kandungan n-3 HUFA dalam rotifera yang dapat memberikan sintasan dan vitalitas larva yang baik adalah $12,90 \%--17,66 \%$ dari total lemak.

\section{DAFTAR PUSTAKA}

Fujita, S., T. Watanabe, and C. Kitajima. 1980. Nutrition quality of Artemia from different location as living feed from viewpoint of essential fatty acids for marine fish. In G. Personne, P. Sorgeloos, O. Roels, and E. Jespers (Eds.). The Brine Shrimp Artemia, Vol. 3 Universa Press, Belgium. p. 277--290.

Furuita, H., T. Takeuchi, T. Watanabe, H. Fujimoto, S. Sekiya, and K. Imaizumi. 1996. Requirement of larval yellowtail for eicosapentaenoic acid, docosahexaenoic, and n-3 highly unsaturated fatty acid. Fisheries Science, 62(3): 372--379.

Izquierdo, M.S., T. Watanabe, T. Takeuchi, T. Arakawa, and C. Kitajima. 1989. Requirement of larvae red sea bream, Pagrus major for essential fatty acids. Nippon Suisan Gakkaishi, 55: 859--867.

Kohno, H., R.S.O. Anguilar, A. Ohno, and Y. Taki. 1997. Why is grouper larval rearing dificult?: An approach from the development of the feeding apparatus in early stage larvae of the grouper, Epinephelus coioides. Ichthyol. Res., 44: 267--274.

Koven, M.W., A. Tandler, G.W. Kissil, D. Sklan, O. Frieslander, and M. Harel. 1990. The effect of dietary n-3 polyunsaturated fatty acid on growth, survival, and swim bladder development in Sparus aurata larvae. Aquaculture, 91: 131--141.

Lee, S.M., J.Y. Lee, Y.J. Khang, H.D. Yoon, and S.B. Hur. 1993. n-3 HUFA requirement of Korean rockfish, Sebastes schlegeli. Bull. Korean Fish. Soc. 26 (5): 477--492.
Lim, C.L. 1993. Larviculture of the grouper Epinephelus tauvina $F$. and the brown-murble grouper Epinephelus fuscoguttatus in Singapore. J. World Aquacult. Soc., 42: 262--274.

Lochmann, R.T. and D.M. Gatlin. 1993. Essential fatty acids requirement of juvenile red drum (Sciaenops ocellatus). Fish Physiol. Biochem., 12: 221--235.

Owen, J.M., J.W. Adron, C. Middleton, and C.B. Cowey. 1975. Elongation and desaturation of dietary fatty acid in Turbot (Scopthalamun maximus) and rainbow trout. Lipid, 10: 258--271.

Salhi, M., M.S. Izquierdo, C.M. Hernandez, M. Gonzalez, and Fernandez Palacois. 1994. Effect of lipid and n3 HUFA levels in microdeits on growth, survival, and fatty acid composition of larval gilthead sea bream (Sparus aurata). Aquaculture, 124: 275--282.

Sargent, J.R., J.G. Bell, M.V. Bell, R.J. Henderson, and D.J. Tocher. 1993. The metabolism of phospholipids and polyunsaturated fatty acids in fish. In: B. Lahlou and P. Vitiello (Eds.), Aquaculture: Fundamental and Applied Research. Coastal and Estuarine Studies, American Geophysical Union, Washington., 43: 103$-124$.

Sorgeloos, P., P. Leger, and P. Laveus. 1988. Improved larval rearing of European, Asian seabass, seabream, mahi-mahi, siganid, and milkfish using enriched diets for rotifer and Artemia. Word Aquacult, 19: 78--79.

Steel, R.G.D. and J.H. Torrie. 1980. Principles and Procedures of Statistics. McGrow Hill, New York, U.S.A.

Suwirya, K., N.A. Giri, dan M. Marzuqi. 2001. Pengaruh n3-HUFA terhadap pertumbuhan dan efisiensi pakan yuwana ikan kerapu bebek, Cromileptes altivelis. In Sudradjat, A., E.S. Heruwati, A. Poernomo, A. Rukyani, J. Widodo, dan E. Danakusuma (Eds.). Teknologi Budi Daya Laut dan Pengembangan Sea Farming di Indonesia, Departemen Kelautan dan Perikanan, p. 201--206.

Suwirya, K., Tridjoko, dan N.A. Giri. 2002. Pola lemak non-polar, polar, dan asam lemak esensial pada perkembangan larva ikan kerapu bebek (Cromileptes altivelis). J. Pen. Per. Indonesia 8(5): 25--31.

Takeuchi, T., T. Arakawa, S. Satoh, and T. Watanabe. 1992. Supplement effect of phospholipids and requirement of eicosapentaenoic acid and docosahexanoic acid of juvenile striped jack. Nippon Suisan Gakkaishi 58(4): 707--713.

Waspada, Mayunar, dan T. Fatoni. 1991. Upaya peningkatan gizi rotifer, Brachionus sp. untuk menunjang keberhasilan pembenihan kerapu macan, Epinephelus fuscoguttatus. J. Pen. Budidaya Pantai 7(2): 73--80.

Watanabe, T., F. Oowa, C. Kitajima, and S. Fujita. 1978 Nutritional quality of brine shrimp, Artemia salina, as a living feed from the viewpoint of essential fatty acids for fish. Bull. Jpn. Soc. Sci. Fish. 44: 1,115--1,121.

Watanabe, T., C. Kitajima, and S. Fujita. 1983. Nutritional values of live organisms used in japan for mass propogation of fish: a review. Aquaculture, 34: 115-143. 
Watanabe, T. 1993. Importance of docosahexaenoic acid in marine larval fish. J. World Aquacult. Soc., 24: $152-161$.

Webster, C.D. and R.T. Lovel. 1990. Respone of stripped bass larvae fed brine shrimp from different sources containing different fatty acids composition. Aquaculture, 90: 49--61.
Yano, Y. and M. Fujii. 1975. Studies on nutrition of red sea bream IX : Effect of $n-3$ fatty acid supplement in acorn oil diet on growth and feed efficiency. Bull. Jpn. Soc. Sci. Fish. 41 : 73--77.

Yunus, N.A. Giri, S. Ismi, dan M. Marzuqi. 2001. Pengaruh jenis pakan awal yang berbeda terhadap pertumbuhan dan sintasan larva kerapu batik (Epinephelus microdon). J. Pen. Per. Indonesia, 7(3): 33--38. 